Short Report

\section{Malaria and mosquitoes: how often for how long?}

\author{
D. Stürchler, U. Naef, M. Fernex, M. L. Mittelhol- \\ zer, R. M. Reber and R. Steffen F. Hoffmann-La \\ Roche AG, CH-4002 Basel, Switzerland and University \\ Institute for Social and Preventive Medicine, Sumatra- \\ strasse 30, CH-8006 Zürich, Switzerland
}

Conceptually, exposure to Anopheles mosquitoes can be divided into an intensity and a duration component. Entomological surveys have characterized the influence of intensity (HII et al., 1988; BURKOT et al., 1988; TRAPE \& ZOULANI, 1987; DEL GIUDICE et al., 1987; DRUILHE et al., 1986): infective bites range from $<0 \cdot 1$ to 3/person/day and vary with Anopheles species, season, and malaria endemicity. Few studies have addressed the influence of duration of exposure. In Peace Corps volunteers working in Africa, fluctuations of quarterly Plasmodium falciparum malaria incidence rates have been observed (BERNARD et al., 1989). In British travellers, the relative risk of malaria was 80 times higher for travels of 27 to 52 weeks' duration compared to travels of 1 week duration (PHILlIPS-Howard et al., 1990). In endemic populations, age is usually taken as a surrogate measure of exposure time (DEL GIUDICE et al., 1987; MOLINEAUX, 1988), assuming stable malaria transmission and absence of population movements.

We have attempted to determine the effect of exposure time on travellers from Switzerland to malarious areas in East and West Africa (STEFFEN $e t$ al., 1990). In this population, exposure ranged from $<1$ week to $>12$ weeks, a time frame which makes confounding by acquired immunity in this nonimmune population unlikely. The confirmed malaria attack rate was $<1 / 1000$ travellers for exposures of $\leqslant 1$ week, and 12/1000 travellers for exposures of 4-12 weeks, a significant 16 -fold increase of relative risk (Table).

Table. Parasitologically confirmed malaria cases in travellers from Switzerland to East and West Africa, classified by length of stay abroad

\begin{tabular}{lccccc}
\hline & $\leqslant 1$ & $2-3$ & $4-12$ & $>12$ \\
\hline Malaria cases per no. of travellers & & & \\
Without prophylaxis & $0 / 183$ & $0 / 371$ & $5 / 61$ & $2 / 6$ \\
With any prophylaxis & $1 / 1210$ & $15 / 13670$ & $5 / 797$ & $0 / 12$ \\
Overall & $1 / 1393$ & $15 / 14041$ & $10 / 858$ & $2 / 18$ \\
Incidence/1000 travellers & $0 \cdot 7$ & $1 \cdot 1$ & $11 \cdot 7$ & $111 \cdot 1$ \\
Relative risk & 1 & $1 \cdot 5$ & $16 \cdot 0$ & 139 \\
$95 \%$ confidence limits & - & $0 \cdot 1-5 \cdot 1$ & $2 \cdot 1-125$ & $13-1476$ \\
\hline
\end{tabular}

Corresponding author: PD Dr D. Stürchler, PKF/TI, F, Hoffmann-La Roche AG, Postfach, CH4002 Basel, Switzerland.
These attack rates are probably confounded by variations in intensity of exposure and protecrive measures in a study population which includes mainly businessmen and tourists. However, our data confirm the correlation between duration of exposure and malaria risk. This finding is expected and plausible, in fact exposure time is shown to be one of the more relevant malaria risk factors for visitors to endemic areas.

\section{References}

Bernard, K. W., Graitcer, P. L., Van der Vlugt, T., Moran, J. S. \& Pulley, K. M. (1989). Epidemiological surveillance in Peace Corps volunteers: a model for monitoring health in temporary residents of developing countries. International foumal of Epidemiology, 18, 220-226.

Burkot, T. R., Graves, P. M., Paru, R., Wirtz, R. A. \& Heywood, P. F. (1988). Human malaria transmission studies in the Anopheles punctulatus complex in Papua New Guinea: sporozoite rates, inoculation rates, and sporozoite densities. American foumal of Tropical Medicine and Hygiene, 39, 135-144.

Del Giudice, G., Engers, H. D., Tougne, C., Biro, S. S., Weiss, N., Verdini, A. S., Pessi, A., Degremont, A. A., Freyvogel, T. A., Lambert, P. H. \& Tanner, M. (1987). Malaria antibodies to the repetitive epitope of Plasmodium falciparum circumsporozoite protein in a rural Tanzanian community: a longitudinal study of 132 children. American foumal of Tropical Medicine and Hygiene, 36, 203-212.

Druilhe, P., Pradier, O., Marc, J. P., Miltgen, F., Mazier, D. \& Parent, G. (1986). Levels of antibodies to Plasmodium falciparum sporozoite surface antigens reflect malaria transmission rates and are persistent in the absence of reinfection. Infection and Immunity, 53, 393-397.

Hii, J. L. K., Kan, S., Vun, Y. S., Chin, K. F., Tambakau, S. \& Chan, M. K. C. (1988). Transmission dynamics and estimates of malaria vectorial capacity for Anopheles balabacensis and Anopheles flavirostris (Diptera: Culicidae) on Banggi island, Sabah, Malaysia. Annals of Tropical Medicine and Parasitology, 82, 91-101.

Molineaux, L. (1988). The epidemiology of human malaria as an explanation of its distribution, including some implications for its control. In: Malaria. Principles and Practice of Malariology, Wernsdorfer, W. H. \& McGregor, I. (editors). Edinburgh: Churchill Livingstone, pp. 913-998.

Phillips-Howard, P. A., Radalowicz, A., Mitchell, J. \& Bradley, D. J. (1990). Risk of malaria in British residents returning from malarious areas. British Medical foumal, $300,499-503$.

Steffen, R., Heusser, R., Mächler, R., Bruppacher, R., Naef, U., Chen, D., Hofmann, A. M. \& Somaini, B. (1990). Malaria chemoprophylaxis in European tourists visiting tropical Africa: use, adverse drug reactions, and efficacy. Bulletin of the World Health Organization, in press.

Trape, J. F. \& Zoulani, A. (1987). Malaria and urbanization in Central Africa: the example of Brazzaville. Part II: results of entomological surveys and epidemiological analysis. Transactions of the Royal Society of Tropical Medicine and Hygiene, 81, supplement no. 1, 10-18.

Received 24 April 1990; revised 11 fune 1990; accepted for publication 12 June 1990 